\title{
ACHIEVING SAFETY AND PRODUCTIVITY IN CONSTRUCTION PROJECTS
}

\author{
Rafiq Muhammad CHOUDHRY \\ Department of Civil and Environmental Engineering, College of Engineering, \\ King Faisal University, Al-Ahsa-31982, Saudi Arabia
}

Received 19 Nov 2014; accepted 21 May 2015

\begin{abstract}
Improvement of safety and productivity are major concerns throughout the construction industry. There is a dearth of efforts that document the need for simultaneous achievement of safety and productivity on construction sites. The objective of this research is to investigate productivity and safety simultaneously on construction projects by conducting a survey. In total, 1,800 hard-copy questionnaires were distributed and the response rate was $81 \%$, resulting in 1,454 valid questionnaires for analysis. Safety and productivity were investigated on 25 construction projects by means of statistical analysis. The results indicated that eleven of the fifteen significant findings pertained to safety and the rest to productivity. The results confirmed that it is possible to improve productivity and safety simultaneously on construction projects. All measures were found to be correlated with both safety and productivity. The findings of this research provide practical knowledge to project managers and safety practitioners on construction projects to achieve safety and productivity simultaneously. The methodology of research might be useful for research at other construction projects in other regions and cultures.
\end{abstract}

Keywords: safety, productivity, construction projects, civil engineering, safety perceptions.

\section{Introduction}

The construction industry is considered as a dangerous industry due to the characteristics of decentralization and mobility (Fang et al. 2006) since employees are separated on construction projects, and they readily move among companies. Frequently, they make on-site decisions about the safe behaviours they deem important. Teo et al. (2005) found that site accidents are more likely to happen when there are inadequate company policies, unsafe practices, and unsafe attitudes of construction personnel, poor management commitment and insufficient safety knowledge and training of workers. Mohamed (2002) developed a research model based on the hypothesis that safe work behaviours are the consequences of the prevailing safety climate. Researchers investigated construction site safety in Hong Kong through behaviour-based safety (Lingard, Rowlinson 1994; Choudhry 2014). Advances in technology resulted in changes to work method (Ahasan 2002) that were compounded to be competitive. Investigators reported that construction is generally risky because of outdoor operations (Shikdar, Sawaqed 2003; Choudhry, Fang 2008), work at heights (Choudhry, Fang 2008), complicated on-site plants and equipment operations (Shikdar, Sawaqed 2003; Choudhry, Fang 2008), and workers' careless attitudes and behaviours towards safety (Choudhry, Fang 2008; Choudhry 2014).
Accidents cause human suffering and economic losses. Computation of the true costs of injuries reveals that compromising safety results in increased costs and decreased profits (Hinze 2000). After understanding "incurring the cost of injuries versus investing in safety" (Hinze 2000), it becomes apparent why such slogans as "Safety Pays; Injuries Cost" and "It Pays to Be Safe" make part of the culture of companies that are truly committed to the well-being of their employees. The International Labour Organization (ILO-OSH 2001) guidelines summarized occupational safety and health as "decent work" which is safe work, and consider that it is a positive factor for productivity and economic growth. There is a growing tendency to shift the responsibility of safety from a separate safety organization or safety department to the management team (Choudhry et al. 2008). Safety officers are re-designated as safety advisors to reveal that the responsibility for safety lies firmly with the project director, project manager, and their line managers. The role of safety advisors is to suggest measures to safeguard a safer working environment. The purpose is to assimilate safety management into project management.

The International Labour Organization (ILO-OSH 2001) and other researchers (Koehn et al. 1995; Koehn, Datta 2003) have emphasized the need for employing a safety management system on construction projects.

Corresponding author: Rafiq Muhammad Choudhry

E-mail: rchoudhry@kfu.edu.sa; choudhry03@gmail.com 
Countries such as the United States and the United Kingdom are implementing safety management regulations such as the Occupational Safety and Health Administration Standards for the construction industry (OSHA 2013), and safety management code of the British Standards Institute (BSI 2000), known as OHSAS 18001 (Occupational Health and Safety Assessment Series 18001) (Lo et al. 2014). A system of safety management practices to accomplish positive safety outcomes through worker engagement are investigated (Wachter, Yorio 2014). Factors affecting construction labour productivity are documented in Kuwait (Jarkas, Bitar 2012). Critical success factors for stakeholder management are investigated in Hong Kong (Yang et al. 2009). Jitwasinkul and Hadikusumo (2011) investigated organizational factors persuading safety work behaviours on construction projects. Forty-five factors affecting labour productivity in building projects in the Gaza Strip are ranked according to their relative importance from a contractor's viewpoint (Enshassi et al. 2007). Additionally, construction activity is widely recognized as a laggard in terms of productivity improvement (Fulford, Standing 2014). Low level of construction productivity issues of contractors are discussed in Singapore (Lim, Alum 1995). Nonetheless, safety and productivity issues have gained vital importance in the competitive global environment. These days, improving worker safety and productivity are main concerns in the construction industry. Organizations are under pressure to produce more with lesser workforce and often with fewer resources. Koller (1989) illustrated some examples of improvements that can be made to workers' health, safety and wellbeing through good work design. Such practices need to be examined to determine if they are adoptable for improving both productivity and safety on construction sites. Essentially, this study is carried out on the construction projects of a leading construction firm in the Hong Kong construction industry, hereinafter called the "company", with the objective of investigating effects of productivity and safety on the overall performance of the company. Perhaps, little research has been conducted, and there is little published data available whether implementing safety on construction sites will affect productivity. Explicitly, the following objectives are identified:

1. To investigate employees' perceptions on productivity and safety which, on the one hand, increase productivity and, on the other hand, improve safety;

2. To understand whether productivity and safety can be assimilated and improved simultaneously in construction projects.

\section{Research method}

This study took place in a leading company with annual revenues of approximately US\$ 1 Billion and employing more than 2,300 full-time staff. The data used in this work were obtained from the survey conducted on 25 construction sites of the company. The questionnaire was mainly adopted from Salminen and Saari (1995) and a pi- lot test was conducted to tailor the questionnaire for this study. For the pilot test, 12 questionnaires were presented to academia and industry experts representing different establishments: clients (3), consultants (3), contractors (3), and universities (3). All 30 items of the questionnaire were modified after rephrasing the questions for the construction sites because Salminen and Saari (1995) had administered their questionnaire in the industrial sector. Based on the pilot test, four additional questions were also added to make the questionnaire appropriate for the construction projects. The drive of the questionnaire was to attain views of the respondents for improving productivity and safety on construction projects.

The final questionnaire consisted of 35 statements about productivity and safety issues at the individual, group and organizational levels and consisted of two parts. The $1^{\text {st }}$ part of the questionnaire related to general facts about the respondents. The five added questions included the respondent's project name, ethnicity, and name of the company. Further questions investigated the respondent's role on the project; whether a worker, supervisor or a manager. The $2^{\text {nd }}$ part consisted of 31 items that inquired the respondents to respond to the statements using a 5-point Likert-scale (where 1 - "strongly disagree", 2 - "disagree", 3 - "neither disagree nor agree", 4 - "agree", and 5 - "strongly agree"). The questionnaire asked the participants to respond, on the Likert-type scale, to each statement, simultaneously considering two major aspects, namely: would "there is an increase in productivity if" and would "there is an improvement in safety if" followed by the question. Thus, the questionnaire was used to investigate productivity and safety simultaneously on construction sites. The researcher issued a cover letter and survey instructions to ensure that all respondents understood that their responses would be anonymous. The questionnaire was prepared both in English and Chinese.

All 25 construction projects of the company were designated for the target sample. The questionnaire distribution targeted all employees working on the construction projects. To maximize the response rate on the projects, top management support of the company was sought. A total of 1,800 hard copy questionnaires were circulated. The response rate was $80.8 \%$, with 1,454 valid questionnaires returned for analysis. The writer was also present on site for directing and monitoring the survey. To avoid the problem of bias, it was decided to interview at least one employee working on each project and thus 25 interviews were conducted with the safety managers, and project managers to collect qualitative information. Qualitative information was also gathered from semi-structured interviews with supervisors and workers to involve diversity of respondents in the research. These interviews delivered a wide-ranging understanding of the industry, safety \& productivity of workers, and site safety.

Most of the responses (79.2\%) were from subcontractor employees and $20.8 \%$ of the respondents were directly employed by the company. In addition, $97.1 \%$ of 
the respondents were Chinese and $2.9 \%$ were non-Chinese. Among the respondents, $77.5 \%$ were workers and supervisors, $16 \%$ were middle managers, and $6.5 \%$ were from top management. The ratio of questionnaires from top management, middle management, and supervisors/ workers was about 2:5:24. The sample was quite representative of the total workforce on the construction sites. Additionally, statistical analysis was carried out by means of the Statistical Package for Social Sciences (SPSS) software. A statistical t-test was conducted to check the population means responses to the subjects raised in the questionnaire.

\section{Results}

The analysis examined the relationship of 31 variables with both productivity and safety. The respondents rated each measure on a 5-point scale so that values 1 and 2 described a low effect and values 4 and 5 described a high effect. The respondents rated the value 3 if they sensed that the quantity had neither a low nor a high effect. Analysis, the t-test results, and correlation of the all variables are shown in Table 1. In this section, the results are also deliberated for further applicability in the construction industry.

The mean score on the factor (Q.1) "there shall be an increase in productivity if more skilled labour is employed" $(m=3.96)$ was significantly greater at the $\mathrm{p}<0.001$ level than the mean score on "there shall be an improvement in safety if more skilled labour is employed" $(\mathrm{m}=3.86)$. The results also showed that a significant correlation exists between these two variables $(\mathrm{r}=0.599, \mathrm{p}<0.001)$, indicating that those who scored high on productivity tend to score high on safety. Researchers, for example Kazmi (2007), indicated that skill development increases productivity of individuals. Enshassi et al. (2007) ranked "lack of labour experience" as the second most important factor which negatively affected labour productivity. They found that skilful workers were more productive because they performed tasks on time. According to impacts on the productivity of craftsmen in Uganda, Alinaitwe et al. (2007) ranked five factors as being most significant which included: 1) incompetent supervisor, 2) lack of skills, 3) rework, 4) lack of tools and equipment, and 5) poor construction methods.

The mean score on the factor (Q.2) "there shall be an increase in productivity if operatives have better education and experience" $(\mathrm{m}=4.02)$ did not differ significantly at the $\mathrm{p}<0.05$ level (note: $\mathrm{p}=0.480$ ) from the mean score on "there shall be an improvement in safety if operatives have better education and experience" $(\mathrm{m}=4.00)$. The results also showed that a significant correlation exists between these two variables $(r=0.663, p<0.001)$, indicating that those who scored high on productivity tend to score high on safety. Koushki et al. (2005) found that the lack of experience of workers reduces profitability causing delays in construction.
The mean score on the factor (Q.3) "there shall be an increase in productivity if operatives get help and advice easily" $(\mathrm{m}=3.79)$ did not differ significantly at the $p<0.05$ level (note: $p=0.840$ ) than the mean score on "there shall be an improvement in safety if operatives get help and advice easily" $(\mathrm{m}=4.00)$. The results also suggest that a significant correlation exists between these two variables $(r=0.679, p<0.001)$, indicating that those who scored high on safety tend to score high on productivity. Good supervisory skills include traits such as: (1) setting a good example on and off the job, (2) praising workers when they have performed a job well, (3) helping workers who had personal problems, (4) showing respect for the workers, and (5) possessing the skills required to motivate workers (Van de Voorde 1991). The writer would like the readers to see (Table 1) for results of question Q.4 to Q.31 as they were not narrated in detail to avoid replication of the questionnaire items.

The factor (Q.4) is about more time and money available for supervising. The writer proposes that it is important for the supervisory staff to be accessible to the workers for good safety performance. A safety manager revealed that intensified safety inspections improve safety and productivity if more time and money are spent. The factor (Q.5) is related to improvement in the safety knowledge of supervisors. Interviews revealed that knowledgeable supervisors comprehend the nature of work, the safe use of tools and equipment, the type of material being used, and the appropriate measures to diminish or eradicate the work hazards for performing safely, as well as doing their tasks in a productive manner. The factor (Q.6) is related to better and frequent controls of site tasks. While conducting interviews, a project manager revealed that the owner was monitoring safety and productivity. The owner required that the prime contractor needed to submit reports. The project manager further revealed that the better controls of site tasks ensure safety and improve productivity. A foreman revealed that performance evaluation needs to be meaningful. Good performance is to be associated with some type of recognition or award.

The factor (Q.7) is narrated to better coordination between the work groups. Project managers revealed that effective coordination facilitates parties (subcontractors, suppliers, crews) to have a clear idea of when they have to start activities and when such activities are to be completed. A project manager of a subcontracting firm revealed that safety and productivity performances of subcontractors are linked to the coordination efforts of the prime contractor. The factor (Q.8) is recounted as there are better personal relations between workmates. Interviewees revealed that better personal relations between workmates ensure success of the work tasks. "If you get along harmoniously with your co-workers, these positive interpersonal relationships provide you happiness at work, achievement, and success", they said. The factor (Q.9) relates that supervisors discourage dangerous work habits. Supervisors play a key role in helping employees 
Table 1. Variables for productivity and safety and their correlations

\begin{tabular}{|c|c|c|c|c|c|c|c|}
\hline & Item & $\begin{array}{l}\text { Mean } \\
\text { (Productivity) } \\
\text { There shall be } \\
\text { an increase in } \\
\text { productivity if }\end{array}$ & $\begin{array}{c}\text { Mean } \\
\text { (Safety) } \\
\text { There shall be } \\
\text { an improvement } \\
\text { in safety if }\end{array}$ & T-test & Sig. & Correlation & Sig. \\
\hline Q.1 & More skilled labor is employed. & 3.96 & 3.86 & 7.224 & 0.001 & 0.559 & 0.001 \\
\hline Q.2 & $\begin{array}{l}\text { Operatives have better education and } \\
\text { experience. }\end{array}$ & 4.02 & 4.00 & 0.707 & 0.480 & 0.663 & 0.001 \\
\hline Q.3 & Operatives get help and advice easily & 3.79 & 4.00 & -0.199 & 0.840 & 0.679 & 0.001 \\
\hline Q.4 & $\begin{array}{l}\text { More time and money are available for } \\
\text { supervising. }\end{array}$ & 3.82 & 4.00 & -8.139 & 0.001 & 0.534 & 0.001 \\
\hline Q.5 & $\begin{array}{l}\text { There is improvement in safety } \\
\text { knowledge of supervisors. }\end{array}$ & 3.88 & 4.04 & -8.460 & 0.001 & 0.600 & 0.001 \\
\hline Q.6 & $\begin{array}{l}\text { There is better and frequent control of } \\
\text { site tasks. }\end{array}$ & 3.89 & 3.93 & -2.071 & 0.039 & 0.591 & 0.001 \\
\hline Q.7 & $\begin{array}{l}\text { There is better coordination between the } \\
\text { work groups. }\end{array}$ & 4.10 & 4.05 & 2.337 & 0.020 & 0.613 & 0.001 \\
\hline Q.8 & $\begin{array}{l}\text { There are better personal relations } \\
\text { between workmates. }\end{array}$ & 4.05 & 4.00 & 2.640 & 0.008 & 0.654 & 0.001 \\
\hline Q.9 & $\begin{array}{l}\text { Supervisors discourage dangerous work } \\
\text { habits. }\end{array}$ & 3.95 & 4.14 & -8.876 & 0.001 & 0.519 & 0.001 \\
\hline Q.10 & Supervisors promotes safe work habits & 3.91 & 4.15 & -11.007 & 0.001 & 0.518 & 0.001 \\
\hline Q.11 & There are intensified safety inspections. & 3.80 & 4.08 & -11.898 & 0.001 & 0.475 & 0.001 \\
\hline Q.12 & $\begin{array}{l}\text { There are intensified accident } \\
\text { investigations. }\end{array}$ & 3.75 & 3.99 & -10.514 & 0.001 & 0.496 & 0.001 \\
\hline Q.13 & $\begin{array}{l}\text { There is strict adherence to time } \\
\text { schedule. }\end{array}$ & 3.85 & 3.77 & 3.846 & 0.001 & 0.580 & 0.001 \\
\hline Q.14 & $\begin{array}{l}\text { There is more emphasis on quality of } \\
\text { work. }\end{array}$ & 3.86 & 3.81 & 2.238 & 0.025 & 0.588 & 0.001 \\
\hline Q.15 & $\begin{array}{l}\text { There is improvement of equipment and } \\
\text { tools. }\end{array}$ & 4.09 & 4.06 & 1.959 & 0.050 & 0.618 & 0.001 \\
\hline Q.16 & There is an increase in the work pace. & 3.80 & 3.57 & 9.387 & 0.001 & 0.560 & 0.001 \\
\hline Q.17 & $\begin{array}{l}\text { Longer time is allowed for work } \\
\text { performance. }\end{array}$ & 3.63 & 3.66 & -1.390 & 0.165 & 0.618 & 0.001 \\
\hline Q.18 & $\begin{array}{l}\text { There is flexibility of production plans } \\
\text { in case of unforeseen problems. }\end{array}$ & 3.85 & 3.82 & 1.395 & 0.163 & 0.580 & 0.001 \\
\hline Q.19 & $\begin{array}{l}\text { There are more safety measures for } \\
\text { equipment. }\end{array}$ & 3.97 & 4.11 & -7.544 & 0.001 & 0.587 & 0.001 \\
\hline Q.20 & $\begin{array}{l}\text { There is improvement and more } \\
\text { awareness of the use of equipment. }\end{array}$ & 3.98 & 4.05 & -4.943 & 0.001 & 0.791 & 0.001 \\
\hline Q.21 & $\begin{array}{l}\text { There is proper use of personal } \\
\text { protective equipment (PPE). }\end{array}$ & 3.88 & 4.05 & -7.771 & 0.001 & 0.473 & 0.001 \\
\hline Q.22 & There is better housekeeping. & 3.97 & 4.04 & -3.672 & 0.001 & 0.656 & 0.001 \\
\hline Q.23 & Work sites are more spacious. & 4.04 & 4.02 & 1.036 & 0.300 & 0.655 & 0.001 \\
\hline Q.24 & $\begin{array}{l}\text { There is better flow of information } \\
\text { between workers. }\end{array}$ & 3.99 & 3.98 & 0.608 & 0.543 & 0.646 & 0.001 \\
\hline Q.25 & $\begin{array}{l}\text { There is better flow of information about } \\
\text { changes on-site. }\end{array}$ & 3.96 & 3.94 & 1.126 & 0.260 & 0.723 & 0.001 \\
\hline Q.26 & $\begin{array}{l}\text { There is proper site work design for } \\
\text { employees. }\end{array}$ & 3.98 & 3.97 & 0.880 & 0.379 & 0.682 & 0.001 \\
\hline Q.27 & $\begin{array}{l}\text { There is no mismatch between employee } \\
\text { abilities and job demands. }\end{array}$ & 3.97 & 3.92 & 2.909 & 0.004 & 0658 & 0.001 \\
\hline Q.28 & $\begin{array}{l}\text { There is no adverse environment such as } \\
\text { heat, noise, light and dust. }\end{array}$ & 3.96 & 3.96 & -0.190 & 0.849 & 0.691 & 0.001 \\
\hline Q.29 & $\begin{array}{l}\text { There is no high absenteeism or lost } \\
\text { work days. }\end{array}$ & 3.97 & 3.82 & 7.148 & 0.001 & 0.547 & 0.001 \\
\hline Q.30 & $\begin{array}{l}\text { There are no complaints of back pain, } \\
\text { neck pain, hand or wrist pain, headache, } \\
\text { stress and or dissatisfaction. }\end{array}$ & 3.91 & 3.94 & -1.414 & 0.158 & 0.708 & 0.001 \\
\hline Q.31 & $\begin{array}{l}\text { There is a hazard analysis and task } \\
\text { analysis. }\end{array}$ & 3.90 & 3.99 & -5.216 & 0.001 & 0.660 & 0.001 \\
\hline
\end{tabular}


to avoid dangerous work habits. Choudhry and Fang (2008) found that workers feel more comfortable with supervisors who care for their safety. Interviews revealed that supervisors help to avoid hiring an unsafe worker. They maintain safe working conditions. They motivate workers to practice safe work habits. Studies indicate that the involvement of foremen and workers are vital elements of a safety management program (Lark 1991; Jaselskis et al. 1996).

The factor (Q.10) communicates that supervisors promote safe work habits. Interviews revealed that safety and productivity benefit all supervisors. They like to promote safe work practices that result in improving productivity. The factor (Q.11) narrates that there were intensified safety inspections. A safety manager revealed that safety improves if inspections are intensified. He gave the example that road safety improves if inspections are intensified to provide feedback to drivers and warning against dangers. Interviews indicated that regular inspections are conducted on construction sites for improving safety and productivity. The factor (Q.12) communicates that there are intensified accident investigations. The author postulates that the challenge of zero accidents lies in prevention efforts including regular feedback to employees, jobsite audits, sharing root cause analysis, and action plans for accident investigations. Productivity improves if site operations are safe. Owing to this, International labour organization (ILO-OSH 2001) summarizes occupational safety and health as "decent work" emphasizing that "decent work" is safe work and is a constructive factor for productivity and economic growth.

The factor (Q.13) is related to strict adherence to the time schedule. Interviews revealed that delays affect productivity to a huge degree and adhering to the schedule improves productivity. A project manager explained that employees tend to adhere to the scheduled hours to maintain productivity. The factor (Q.14) narrates that there is more emphasis on the quality of work. Interviews explained that when a decline in quality is realized, there is an increased emphasis on quality. This increase in quality pressure serves to improve quality; however, an increase in quality serves to decrease productivity because there is more of an emphasis on getting it right than getting it done. According to Deming (2000) quality reduces expenses while increasing productivity and market share. The factor (Q.15) communicates about improvement of equipment and tools. Safety managers revealed that if workers are provided with insufficient tools and equipment to do their job, obviously, the productivity is low. Productivity improves if workers are provided with faster machines. Interviewees explained that there are general norms to use machines and replace humans to improve productivity. They explained that sometimes even minor ergonomic changes in the design of equipment can make significant improvements in worker comfort, health, safety and productivity. Nonetheless, the participants were of the view that accidents happen if equipment is not safely operated, inspected and maintained.
The factor (Q.16) is related to increase in the work pace. Changes in the work pace can affect productivity and safety. A project manager revealed that crashing of a schedule (to produce more in a shorter time) needed to be done very carefully ensuring that safety is not compromised. The factor (Q.17) concerns that longer time is allowed for work performance. Interviews conducted revealed that one may accomplish more by working longer hours; however, this increase in productivity is not farreaching. They explained that small breaks improve concentration and safety; however, long breaks affect the performance. Also, working long hours' increases fatigue and, when sustained, does not increase productivity and safety. Rather, it actually reduces safety and productivity; therefore, a balance is suggested. The factor (Q.18) narrates that there is flexibility of production plans in case of unforeseen problems. Interviews revealed that the company is under constant pressure to produce more and increase productivity. An interviewee said that the company has increased the use of tools and information technology to increase productivity and safety on its construction sites.

The factor (Q.19) reveals that there are more safety measures for equipment. A safety director revealed that well-designed equipment is easy to use and helps in increasing productivity. He said, "If one is concerned about safety while using equipment, one must stop it and contact a competent person to undertake a more thorough check". Interviews further revealed that equipment use in terms of size, shape and controls improves performance and productivity on construction sites. The factor (Q.20) communicates that there is improvement and increased awareness of the use of equipment. The writer postulates that the use of appropriate equipment and new technology enhances output of workers. Additionally, more regular use of equipment significantly improves working in an office. For example, if there is a fax machine in the office, office staff often improves in involvement and awareness. Interviewees explained that increased awareness and a more efficient use of equipment improve productivity. They further revealed that equipment allows employees to do their jobs better. Participants were of the view that safety risks are significantly reduced by providing safety orientation and equipment awareness training. The factor (Q.21) narrates that there is proper use of personal protective equipment. An interviewee revealed that if the company is seeking to improve health and safety performance, it needs to train its staff on adaptation and use of personal protective equipment. Another interviewee said, "Increase in productivity is possible by safe and proper handling of chemicals and by using relevant personal protective equipment (PPE)". "If several different types of PPE are worn together, workers need to make sure they are compatible", he said.

The factor (Q.22) is related to better house-keeping. Good house-keeping means cleanliness and good order of equipment in their use on the jobsite. The writer postulates that good housekeeping improves productivity when 
the right tools and materials are easy to find to carry out the job. Interviews revealed that good housekeeping with better hygienic conditions leads to improved health and safety by providing more effective use of space. They explained that the company has a strong commitment to continuous improvement by ensuring good housekeeping, clear passageways, and internal traffic control on their construction sites. The factor (Q.23) recounts that work sites are more spacious. An interviewee indicated that if you want your team to be more successful, then you need to create an open and spacious work environment so that your engineers feel relaxed. Another interviewee further revealed that productivity of work will increase definitely to a certain extent because of spacious environment. There is a lot one needs to do to improve the jobsite and the office to look tidy. He said, "Ensure cleanliness and for instance, offices look spacious because you have removed all unnecessary stuff". The factor (Q.24) represents that there is better flow of information between workers. Interviews revealed that workers feel competent if they share their ideas related to safety and productivity. Workers also feel comfortable if there is a clear flow of information from top and middle management. A manager indicated that information needs to be provided in a clear manner by using a simple information sheet.

The factor (Q.25) reveals that there is better flow of information about changes on-site. Project managers were of the view that changes to the site work need to be communicated in writing and, an adequate time is required for adjustment to the changes. Interviews further represented that productivity and safety are linked if changes are managed efficiently. A manager needs to stop site work if there is not an efficient flow of information, for example, the required drawings are not available for construction. The factor (Q.26) narrates that there is proper site work design for employees. Shikdar and Sawaqed (2003) reported that some of the common problems faced by the oil industry are improper workplace designs, mismatch between worker abilities and job demands, adverse environments, poor human-machine system designs, and inappropriate management programs. These problems are equally applicable to the construction industry. Interviews revealed that the company is committed to improve employees' productivity by providing good site work design for their employees. Interviewees further indicated that ergonomics and better job-site environment help in improving productivity and safety. Koller (1989) documented some improvements that were incorporated to workers' health, safety and wellbeing through good work design. The factor (Q.27) describes that there is no mismatch between employee abilities and job demands. Enshassi et al. (2007) concluded that "skilfulness of worker improves safety" factor was ranked in the $1^{\text {st }}$ position among the 28 factors with regard to its importance in sustaining safety and productivity of projects. Interviews revealed that productivity increases provided workers are skilled relevant to their jobs. An interviewee described that if there is mismatch between the skills needed for the job and the skills of the employee who does not know how to operate the machine, then the productivity drops. Another interviewee revealed that employee feel more motivated and less stressed if their job matches to their ability, and this has a positive effect on safety and productivity.

The factor (Q.28) describes that there is no adverse environment such as heat, noise, light and dust. Interviews indicated that the company management is committed that the work environment is required to be safe and healthy. An interviewee pointed out that adverse effects are caused by various factors, for example, dust causes dust-related diseases such as cancer or asthma. Another interviewee described that adverse health consequences occur due to noise, temperature, ventilation, lighting, vibration, radiation, gases, and air quality that effect safety and productivity. The factor (Q.29) indicates that there is no high absenteeism or lost work days. An interviewee revealed that absenteeism causes loss in productivity for the company. Another interviewee revealed that there is a great deal of time and money losses associated with absenteeism in the company. Interviewees agreed that sick days and lost work days also cost the company. The factor (Q.30) reveals that there are no complaints of back pain, neck pain, hand or wrist pain, headache, stress and or dissatisfaction. The interviewees explained that all the company employees have medical insurance to visit hospitals. There is also first aid available at all projects of the company and employees are referred to hospitals if they have complaints of fatigue, back pain, upper-body pain, hand or wrist pain, and headache etc. Shikdar and Sawaqed (2003) indicate that these issues decrease worker productivity and a significant correlation exists among productivity indicators, health and organizational attributes. The factor (Q.31) describes that there is a hazard analysis and task analysis. A job hazard analysis concentrates on job tasks as a way to recognize hazards before they occur. Hazard analysis focuses on the relationships between the workers, the tasks, the tools, and the work environments. Task analysis is a family of measures to recognize the content of a job in terms of activities involved and job requirements needed to perform the undertakings. A job task analysis provides data to organizations that helps to control which employees are best fit for specific tasks. The analyst needs to comprehend what the significant tasks of the job are, how they are performed, and the necessary human abilities required to complete the job successfully. Kazaz and Ulubeyli (2007) reported that on-site hazard, poor workers' health and injuries on construction sites decrease productivity and increase costs. Interviewees reported that hazard analysis and task analysis are carried out on-site to increase productivity and safety. An interviewee explained that it is prerequisite to identify potential hazards because if you identify hazards, you can take steps to remove or reduce them to an acceptable risk level. 
Table 2. Measures rated as most effective for improving productivity and safety

\begin{tabular}{ll}
\hline \multicolumn{1}{c}{ Productivity } & \multicolumn{1}{c}{ Safety } \\
\hline Better coordination between the work groups & Supervisors promotes safe work habits \\
Improvement of equipment and tools & Supervisors discourage dangerous work habits \\
Better personal relations between workmates & More safety measures for equipment \\
More spacious work sites & Intensified safety inspections \\
More skilled labor & Improvement of equipment and tools \\
\hline
\end{tabular}

From the results of the t-test, the five factors having the highest scores on providing the most perfection in productivity and safety simultaneously are shown in Table 2. For productivity, coordination between work groups and improvement of equipment and tools were rated the highest. Better personal relations between workmates, more spacious work sites, and the use of more skilled labour were the highest rated factors for improving productivity. For safety, the supervisors' role in promoting safe work habits and discouraging dangerous work habits was rated the highest. Providing more safety measures for equipment, safety inspections and improvement of equipment and tools were the highest rated factors for improving safety. The respondents perceived that productivity and safety simultaneously increase with better coordination and with measures improving site work conditions. The respondents perceived that it was possible to improve safety and productivity simultaneously with measures that decreased work hazards.

\section{Conclusions}

While achieving the established objectives, this work determined the differences between respondents' perceptions of how the variables itemized in the questionnaire affect productivity and safety. Eleven (11) of the fifteen (15) statistically significant differences were in the course of safety, and only four (4) favoured productivity. The factors stressed the engagements of supervisors as a means to improve safety, as seven significant differences dealt with supervisors. These seven factors included: (1) more time and money are available for supervising, (2) improvement in safety knowledge of supervisors, (3) supervisors discourage dangerous work habits, (4) supervisors promotes safe work habits, (5) intensified safety inspections, (6) ensuring proper use of personal protective equipment, and (7) ensuring better housekeeping. The four factors that favour safety were: (1) intensified accident investigations, (2) more safety measures for equipment, (3) improvement and more awareness of the use of equipment, and (4) hazard analysis and task analysis. Additionally, operatives easily getting help and advice, better and frequent control of site tasks, longer time allowed for work performance, and no adverse environment (e.g. heat, noise, light, and dust) were perceived to be means that can help improve safety.

Four (4) statistically significant differences that played their role to increase productivity were: (1) more skilled labour is employed, (2) strict adherence to time schedule, (3) increase in work pace, and (4) no high absenteeism or lost work days. Additionally, operatives having better education and experience, better coordination between the work groups, better personal relations between workmates, emphasis on quality of work, improvement of equipment and tools, flexibility of production plans in case of unforeseen problems, more spacious work sites, better flow of information between workers, better flow of information about changes on-site, proper site work design for employees, no mismatch between employee abilities and job demands were thought to be means that can help improve productivity.

The five factors providing the maximum enhancement in productivity and safety were identified from the t-test. The identified factors for productivity included: better coordination between work groups, improvement of equipment and tools, better personal relations between workmates, spacious work sites, and use of more skilled labour. The five factors as the best means for improving safety were identified: supervisors' promoting safe work habits, supervisors' discouraging dangerous work habits, more safety measures for equipment, safety inspections, and improvement of equipment and tools. Considering the relationship between productivity and safety, all 31 measures were established to be significantly correlated with both improvements in productivity and safety. The findings provide practical knowledge to engineers, safety managers, safety practitioners, and project managers who desire to improve safety and productivity in construction projects.

\section{References}

Ahasan, R. 2002. Human adaptation to shift work in improving health, safety and productivity - some recommendations, Work Study 51(1): 9-16. http://dx.doi.org/10.1108/00438020210415479

Alinaitwe, H. M.; Mwakali, J. A.; Hanson, B. 2007. Factors affecting the productivity of building craftsmen - studies of Uganda, Journal of Civil Engineering and Management 13(3): 169-176.

British Standards Institute (BSI). 2000. Occupational health and safety management system: guidelines for the implementation of OHSAS 18001. Publication No. BSI-02-2000, London, UK.

Choudhry, R. M.; Fang, D. P. 2008. Why operatives engage in unsafe work behavior: investigating factors on construction sites, Safety Science 46(4): 566-584. http://dx.doi.org/10.1016/j.ssci.2007.06.027 
Choudhry, R. M.; Fang, D. P.; Ahmed, S. 2008. Safety management in construction: best practices in Hong Kong, Journal of Professional Issues in Engineering Education \& Practice 134(1): 20-32.

http://dx.doi.org/10.1061/(ASCE)1052-3928(2008)134:1(20)

Choudhry, R. M. 2014. Behavior-based safety on construction sites, Accident Analysis and Prevention 70(9): 14-23. http://dx.doi.org/10.1016/j.aap.2014.03.007

Deming, W. E. 2000. Out of the crisis. Cambridge: The MIT Press. 507 p.

Enshassi, A. A.; Mohamed, S.; Mustafa, Z. A.; Mayer, P. E. 2007. Factors affecting labour productivity in building projects in the Gaza Strip, Journal of Civil Engineering and Management 13(4): 245-254.

Fang, D. P.; Chen, Y.; Wong, L. 2006. Safety climate in construction industry: a case study in Hong Kong, Journal of Construction Engineering and Management 132(6): 573-584.

http://dx.doi.org/10.1061/(ASCE)0733-9364(2006)132:6(573)

Fulford, R.; Standing, C. 2014. Construction industry productivity and the potential for collaborative practice, International Journal of Project Management 32(2): 315-326. http://dx.doi.org/10.1016/j.ijproman.2013.05.007

Hinze, J. 2000. Incurring the cost of injuries versus investing in safety, Chapter 2 in R. J. Coble, J. W. Hinze, T. C. Haupt (Eds.). Construction safety and health management. New Jersey: Prentice Hall.

International Labor Organization. Occupational Safety and Health (ILO-OSH). 2001. Guidelines on occupational safety and health management systems. Geneva, Switzerland. 37 p.

Jarkas, A. M.; Bitar, C. G. 2012. Factors affecting construction labor productivity in Kuwait, Journal of Construction Engineering and Management 138(7): 811-820. http://dx.doi.org/10.1061/(ASCE)CO.1943-7862.0000501

Jaselskis, E. J.; Anderson, S. D.; Russell, J. S. 1996. Strategies for achieving excellence in construction safety performance, Journal of Construction Engineering and Management 122(1): 61-70.

http://dx.doi.org/10.1061/(ASCE)0733-9364(1996)122:1(61)

Jitwasinkul, B.; Hadikusumo, B. H. W. 2011. Identification of important organizational factors influencing safety work behaviors in construction projects, Journal of Civil Engineering and Management 17(4): 520-528. http://dx.doi.org/10.3846/13923730.2011.604538

Kazaz, A.; Ulubeyli, S. 2007. Drivers of productivity among construction workers: a study in a developing country, Building and Environment 42(5): 2132-2140. http://dx.doi.org/10.1016/j.buildenv.2006.04.020

Kazmi, S. W. 2007. Vocational education and skills development: a case of Pakistan, SAARC Journal of Human Resource Development 3: 105-117.

Koushki, P. A.; Al-Rashid, K.; Kartam, N. 2005. Delays and cost increases in the construction of private residential projects in Kuwait, Construction Management and Economics 23: 285-294. http://dx.doi.org/10.1080/0144619042000326710

Koehn, E. E.; Datta, N. K. 2003. Quality, environmental, and health and safety management system for construction engineering, Journal of Construction Engineering and Management 129(5): 562-569.

http://dx.doi.org/10.1061/(ASCE)0733-9364(2003)129:5(562)

Koehn, E. E.; Kothari, R. K.; Pan, C.-S. 1995. Safety in developing countries: professional and bureaucratic problems, Journal of Construction Engineering and Management 121(3): 261-265.

http://dx.doi.org/10.1061/(ASCE)0733-9364(1995)121:3(261)

Koller, M. 1989. Preventive health measures for shift workers, in M. Wallace (Ed.). Managing shift work. Melbourne: Brain Behaviour Research Institute, 17-24.

Lark, J. 1991. Leadership in safety, Professional Safety 36(3): 33-35.

Lim, E. C.; Alum, J. 1995. Construction productivity: issues encountered by contractors in Singapore, International Journal of Project Management 13(1): 51-58. http://dx.doi.org/10.1016/0263-7863(95)95704-H

Lingard, H.; Rowlinson, S. 1994. Construction site safety in Hong Kong, Construction Management and Economics 12(6): 501-510.

http://dx.doi.org/10.1080/01446199400000061

Lo, C. K. Y.; Pagell, M.; Fan, D.; Wiengarten, F.; Yeung, A. C. I. 2014. OHSAS 18001 certification and operating performance: the role of complexity and coupling, Journal of Operations Management 32(5): 268-280.

http://dx.doi.org/10.1016/j.jom.2014.04.004

Mohamed, S. 2002. Safety climate in construction site environments, Journal of Construction Engineering and Management 128(5): 375-384.

http://dx.doi.org/10.1061/(ASCE)0733-9364(2002)128:5(375)

Occupational Safety and Health Administration (OSHA) [online]. 2013 [cited 10 January 2014]. Available from Internet: www.osha.gov.

Salminen, S.; Saari, J. 1995. Measures to improve safety and productivity simultaneously, International Journal of Industrial Ergonomics 15(4): 261-269. http://dx.doi.org/10.1016/0169-8141(94)00042-2

Shikdar, A. A.; Sawaqed, N. M. 2003. Worker productivity and occupational health and safety issues in selected industries, Computers \& Industrial Engineering 45(4): 563572. http://dx.doi.org/10.1016/S0360-8352(03)00074-3

Teo, E. A. L.; Ling, F. Y. Y.; Chong, A. F. W. 2005. Framework for project managers to manage construction safety, International Journal of Project Management 23(4): 329-341. http://dx.doi.org/10.1016/j.ijproman.2004.09.001

Van de Voorde, J. 1991. Work-related injury frequency rates in the Navy Seabees: Unpublished Master's research report. University of Washington, USA.

Wachter, J. K.; Yorio, P .L. 2014. A system of safety management practices and worker engagement for reducing and preventing accidents: an empirical and theoretical investigation, Accident Analysis and Prevention 68(7): 117-130. http://dx.doi.org/10.1016/j.aap.2013.07.029

Yang, J.; Shen, G. Q.; Ho, M.; Drew, D. S.; Chan, A. P. C. 2009. Exploring critical success factors for stakeholder management in construction projects, Journal of Civil Engineering and Management 15(4): 337-348. http://dx.doi.org/10.3846/1392-3730.2009.15.337-348

Rafiq Muhammad CHOUDHRY. Professor of Construction Engineering and Management in the Department of Civil and Environmental Engineering at King Faisal University, Saudi Arabia with over 24 years of industry, research and teaching experience. His research interests include occupational safety and health, contract management, risk management, planning and scheduling, organisational structure and culture in the construction industry. He organized number of conferences and seminars. He has published over 75 papers in refereed journals and conferences. 